\title{
More from the Horse's Mouth: What Scientists Say about Science as a Social Practice
}

Wong, S. L. and Hodson, D. (2010). More from the horse's mouth: What scientists say about science as a social practice. International Journal of Science Education. 32(11), 1431-1463.

ABSTRACT: This research study sought to identify prominent features of the nature of science (NOS) embedded in authentic scientific inquiry. Fourteen well-established scientists from different parts of the world, working in experimental or theoretical research, in both traditional fields such as astrophysics and rapidly growing research fields such as molecular biology, participated as the informants of the study. The descriptions of their practices revealed eight prominent categories of NOS features. In an earlier paper (Wong \& Hodson, 2009a), we have reported four categories under the two themes: (1) the methods of scientific investigation and (2) the role and status of scientific knowledge. In this paper, we focus on the remaining four categories under the theme: social dimensions of science. Scientists' descriptions of their practices have 'put some flesh on the bones' of the assertion that science is socially and culturally embedded. These descriptions also have considerable potential for development into interesting case studies as teaching resources to enhance and enrich students' understanding of NOS. 


\section{INTRODUCTION}

The past 15 years has seen a steady growth in the number of curriculum reform documents advocating an increased emphasis on teaching about the nature of science (NOS) - see, for example, AAAS (1993), UNESCO (1993), National Research Council (1996), Council of Ministers of Education (1997), Millar and Osborne (1998), OECD (1999), Goodrum, Hackling, and Rennie (2000), Department of Education (2002) ${ }^{1}$. In making the case for a more prominent role for NOS in the curriculum, Driver, Leach, Miller, and Scott (1996) contend that in addition to its intrinsic value as a key element of general scientific literacy, it enhances the learning of science content, generates interest in science and develops students' ability to make informed decisions on socioscientific issues (SSI). The latter argument holds that democracy is strengthened when all citizens are equipped to confront and evaluate SSI knowledgeably and rationally, and that the capacity to do so is enormously enhanced by robust NOS understanding. However, while there have been strenuous efforts to develop and implement more effective NOS-oriented curricula, research findings continue to paint a depressing picture of NOS understanding among students and their teachers (AbdEl-Khalick \& Lederman, 2000; Driver et al. 1996; Finson, 2002; Hogan \& Maglienti, 2001; Lederman, 1992; Moss, Abrams, \& Robb, 2001; Ryder, Leach \& Driver, 1999). Of course, the goal of improving NOS understanding is often prejudiced by the inadequate, incomplete, confused and confusing images of science that are consciously or unconsciously built into school science curricula and perpetuated by science textbooks (Hodson, 1998; McComas, 1998). In addition, for many teachers, there is continuing anxiety about the robustness of their own NOS knowledge and uncertainty about the most effective way of teaching for NOS understanding. 
Ever since the major curriculum reforms of the 1960s, science teachers have been confronted with the twin tasks of teaching students the products of science (concepts, ideas, models and theories) and giving them some understanding of how those products arise. But even with the increased curriculum emphasis on NOS, it could be argued that many science teachers continue to emphasize what Bruno Latour (1987) calls "ready made science” (with all its attendant implicit messages about certainty achieved through systematic application of a rigorous method or methods) rather than “science-in-the-making” (with its emphasis on social construction). As Calabrese Barton and Yang (2000) comment, “textbooks and other curricular materials often hide the people, tools, and social contexts involved in the construction of science. The result is often a fact-oriented science which appears decontextualized, objective, rational, and mechanistic” (2000, p. 875). The drive to equip students with an understanding of science in its social, cultural, economic and political contexts is, of course, the underpinning rationale of the so-called science-technology-society (STS) approach - more recently expanded to STSE (where E stands for environment). James Gallagher (1971), one of the pioneers of STS education, captures its overall flavour particularly well.

For future citizens in a democracy, understanding the interrelations of science, technology, and society may be as important as understanding the concepts and processes of science. An awareness of the interrelations between science, technology, and society may be a prerequisite to intelligent action on the part of a future electorate and their chosen leaders. (1971, p.337)

Aikenhead (2005, 2006) describes how the frequent references to values and social responsibility in the STS literature were systematized by utilizing a theoretical framework deriving from sociology of science: first, consideration of the interactions of science and scientists with social aspects, issues and institutions external to the community of scientists; second, focus on the social interactions of scientists within 
the scientific community. More recently, Weinstein (2008) has identified four social aspects of science that warrant attention in the school curriculum: science as investigation (that is, science as a set of agreed practices); science as work (recognition that science is not just a matter of conducting experiments to test fledgling hypotheses; it involves grant writing, conferences, critiques and publications); science as enterprise (dealing with profit, patent, political economy, interest, lobbying, legislation and funding) and science as culture (science as embedded in wider cultural, political and historic contexts). It is the social context in which scientific practice is located that forms the substance of this paper.

\section{WHAT NOS KNOWLEDGE SHOULD WE TEACH?}

Some twenty years ago, Laudan et al. (1986) stated:

We have no well-confirmed general picture of how science works, no theory of science worthy of general assent... If any extant position does provide a viable understanding of how science operates, we are far from being able to identify which it is” (p.42)

More recently, a questionnaire-based survey of the views of 210 philosophers of science led Alters (1997) to essentially the same conclusion. More recently still, Stanley and Brickhouse (2001) commented, “although almost everyone agrees that we ought to teach students about the nature of science, there is considerable disagreement on what version of the nature of science ought to be taught” (2001, p.47). In contrast, McComas and Olson (1998) report substantial agreement within a number of recent science curriculum reform documents produced in the United States, United Kingdom, Canada, Australia and New Zealand concerning the elements of NOS that should be included in the school science curriculum - a view endorsed by Cobern and Loving (2001). Further, Abd-El-Khalick, Bell, and Lederman (1998) assert that while philosophers and sociologists might disagree on some aspects of NOS, most of the 
disagreements are "irrelevant to K-12 instruction... far too abstract for K-12 students to understand and far too esoteric to be of immediate consequence to their daily lives” (1998, p.418). Good and Shymansky (2001), however, question whether there really is a consensus in the documents cited by McComas and Olson, arguing that there are major inconsistencies between and within the lists of NOS items in Benchmarks for Scientific Literacy (AAAS, 1993) and National Science Education Standards (NRC, 1996), depending on whether one adopts a philosophy of science perspective or a history of science perspective - a point that is of particular relevance to the specific focus of this article.

When disagreements arise, whose views of NOS should count? Should we defer to philosophers of science, on the grounds that they spend the whole of their professional lives grappling with the important questions? "No" say Smith, Lederman, Bell, McComas, and Clough (1997),-because their concerns are "esoteric, inaccessible, and probably inappropriate for most K-12 instruction” (1997, p.1102). Should we rely on historians of science, on the grounds that a robust theory of science must stand up to close historical scrutiny? ${ }^{\mathbb{Z}}$ Should we put our trust in scientists, on the grounds that those engaged on a day-to-day basis with the enterprise of science must know what it entails? Or should we put our faith in sociologists and ethnographers? In an effort to accommodate these different constituencies, Osborne, Collins, Ratcliffe, Millar, and Duschl (2003) conducted a Delphi study to determine the extent of agreement concerning ideas-about-science that should be taught in school science among 23 members of the "expert" community: five scientists, five persons categorized as historians, philosophers and/or sociologists of science, five science educators, four science teachers and four science communicators. There was broad agreement on nine major themes: scientific method and critical testing; creativity; historical development 
of scientific knowledge; science and questioning; diversity of scientific thinking; analysis and interpretation of data; science and certainty; hypothesis and prediction; cooperation and collaboration. Comparison with the NOS items deriving from the analysis of science education standards documents by McComas and Olson (1998) reveals many similarities. Moreover, a strikingly similar list can be found in Lederman, Abd-El-Khalick, Bell, and Schwartz (2002): science is tentative, empirically based, subjective (in the sense of being theory-driven), socioculturally embedded and dependent on human imagination and creativity. These authors are also concerned that students appreciate that there is no one scientific method, draw a distinction between observation and inference, and recognize the difference between theories and laws. ${ }^{3}$

At present, the elements of NOS included in science curriculum standards documents and built into curriculum experiences (of whatever kind) are, by and large, a distillation of the literature generated by philosophers, historians and sociologists of science. While we acknowledge the value of this scholarship, we urge that these pronouncements on scientific practice be tempered by reflective critical comments from practising scientists. We believe that scientists who work at the frontiers of science can play an important role in refining and developing science educators' views about the practices of the science community, the nature of scientific work, the aims behind it, and the inter-relationships with the society in which it is embedded. We are also cognizant of the views of Elby and Hammer, who argue that the current consensual list of NOS items is too general and too broad, and concur with their claim that "a sophisticated epistemology does not consist of blanket generalizations that apply to all knowledge in all disciplines and contexts; it incorporates contextual dependencies and judgments” (2001, p.565). Rudolph has also argued that teachers 
should acknowledge the context-dependency of scientific practice and knowledge generation:

Educators need to begin to exploit the vast literature of the science studies community, not to develop some universalist picture of science, the value of which is questionable, but to begin to understand what the various practices of science look like in all their myriad forms, in order to provide some reasonably authentic context in which to situate the scientific knowledge claims of the curriculum (p. 409).

While supportive of Rudolph's proposal to utilize the work of sociologists and ethnographers of science, we also urge teachers not to rely solely on their views of what constitutes an authentic view of science and scientific practice. Scientists' views should also be sought and utilized in curriculum construction. As Wolpert (1994) and Labinger (1995) remind us, scientists frequently don't recognize themselves or their actions in some of the ethnographic studies that have been published in recent years. The perspectives on NOS provided by active practitioners in the science community are likely to focus primarily on day-to-day practices rather than wider epistemological issues. We see them as a means to illuminate, enhance, enrich and qualify the views provided by experts in other communities.

We are not alone in paying attention to the voices of scientists. For example, Glasson and Bentley (2000) interviewed four scientists and two engineers following a conference designed to acquaint science teachers with current research practice. All the scientists emphasized the importance of research design in obtaining valid and reliable data, though they noted that what constitutes good design is contingent on the specific circumstances of the inquiry. More recently, Samarapungavan, Westby, and Bodner (2006) compared the NOS beliefs of 13 research chemists with those of chemistry students ranging from high school to postgraduate level. The authors conclude that the current characterization of NOS in science education may underrepresent discipline-specific aspects of science. Although the scientists interviewed by 
Schwartz and Lederman noted that scientific investigation and theory building proceed in diverse ways, depending on the field, there was a clear indication by some (9 out of 24) that "claims made through experimental methods were more valid than claims made through non-experimental methods” (p.13). On the question of whether scientific investigations need to be hypothesis-driven, chemists and life scientists said “yes”, while earth scientists and space scientists said “no”. Context seems, again, to be the crucial consideration. Interestingly, Schwartz and Lederman (2008) report that differences in investigative approaches among the 24 scientists in their research sample are not so much illustrative of distinctive features of the broader subdisciplines of chemistry, physics, biology and earth sciences as a consequence of differences in the specific contexts and experiences of individual scientists.

\section{HOW SHOULD WE TEACH NOS?}

Although we acknowledge that students' NOS understanding4 is strongly influenced by informal learning experiences - what students learn about science from movies, television, newspapers and magazines, websites, advertising campaigns, and visits to museums, zoos, aquaria, nature reserves, field centres, and the like - we have chosen to focus this article on the ways in which formal educational experiences impact on that understanding. In simple terms, curriculum experiences can be regarded as comprising two kinds: those that we explicitly plan and those that we do not. It is common for school textbooks to carry explicit messages about science, particularly in early chapters that tell students what science is about and what scientists do when they are conducting investigations. In addition, there are explicit references to the nature of science and the history of science in many STS-oriented materials and case studies, many teachers are concerned to emphasize important features of scientific inquiry 
during laboratory activities, and some teachers provide purpose-made NOS-oriented course units. Just as frequently, however, messages about the nature of science, scientists and scientific practice are not consciously planned. Rather, they comprise a set of implicit messages embedded in the language teachers use, the kind of teaching and learning activities they employ (especially in laboratory work), the examples of science and scientists they cite, and so on. There are also approaches that consciously seek to bring about particular NOS understanding (i.e., they have an explicit intention) but seek to do so by indirect means. Here the intention is that students recognize the features of science and acquire NOS understanding as a consequence of engaging in learning activities primarily intended for other purposes. Abd-El-Khalick and Lederman include these indirect but purposeful approaches under the heading of implicit approaches Thus, the distinction they draw (between explicit and implicit approaches) resides not so much in the kind of activities used (hands-on inquiries, historical case studies, lectures, and so on) as in the

...extent to which learners are provided (or helped to come to grips) with the conceptual tools, such as some key aspects of NOS, that would enable them to think about and reflect on the activities in which they are engaged” (2000, p.690).

Their review of 17 interventions designed to enhance teachers' conceptions of the nature of science, eight of which they characterize as implicit approaches, nine as explicit approaches, concludes that "an explicit approach was generally more 'effective' in fostering 'appropriate' conceptions of NOS among prospective and practising teachers” (p.692). In an explicit approach, NOS understanding is regarded as “content”, to be approached carefully and systematically, as with any other lesson content. Although that content can be addressed in many different ways, it is essential that students have ample and appropriate opportunities to reflect on key NOS issues. 
It should be emphasized that regarding NOS knowledge as content does not necessarily entail a didactic or teacher-centred approach, but it does entail a rejection of the belief that NOS understanding will just develop in students as a consequence of engaging in particular activities (Aikenhead, 1973). It also entails clarity about what items of NOS knowledge are considered important for the school curriculum.

The earlier distinction between "ready made science" and "science-in-themaking” is also relevant here. Our interest in this paper focuses on teaching and learning experiences that foster understanding of the latter orientation, what some have called authentic science, as preparation for confronting SSI and playing an active role as a responsible citizen. A number of science educators argue that a clear understanding of what constitutes authentic scientific practice can best be acquired, and perhaps can only be acquired, by first-hand apprenticeship experience in a laboratory or field setting (Helms, 1998; Roth, 1995). Not only are these internship experiences difficult to provide for every student, especially in Asian countries such as China, Japan and Korea, where class sizes are commonly as high as 50 students, they do not always bring about the desired understanding as quickly and straightforwardly as intended. As Bell, Blair, Crawford, and Lederman (2003) and Schwartz, Lederman, and Crawford (2004) report, it seems that it is not the doing science activity per se that is key to developing robust understanding, but reflection on these experiences through journal writing and seminars. Extended project work, in which students identify the areas of concern, formulate the research questions, design the investigation, collect, interpret and report the data, and argue for particular conclusions, is authentic science from the perspective of the student. Such experiences can be enormously enhanced by providing opportunities for students to 
consult practising scientists via contacts with a local university or college (Bencze \& Hodson, 1999).

There is also some encouraging evidence that well-designed historical case studies can be effective in bringing about NOS understanding. For example, Irwin (2000) reports encouraging results with a group of 14-year-old students when substantial amounts of historical material were integrated into the topic of Atoms and the Periodic Table. Lin and Chen (2002) also provide empirical evidence of positive impact on understanding of NOS among a group of prospective chemistry teachers by integrating historical cases into their pre-service teacher education programme. It is our contention that case studies of contemporary practice (science-in-the-making) would be even more effective. With historical case studies there is often a tendency for students to interpret events from their existing scientific perspectives, so they often fail to recognize the nature of the scientific problems existing at the time. Students may also have difficulty in relating to the sociocultural and economic milieu surrounding the events, and fail to fully appreciate why particular scientific problems were considered important. With case studies of contemporary practice, both shortcomings are minimized.

\section{THE SOCIOCULTURAL DIMENSION}

It is noteworthy that gains in NOS understanding consequent on exposure to explicit, reflective instruction, whatever specific pedagogical form it takes, are often less substantial in relation to the sociocultural dimensions of science than with other NOS elements (Akerson, Abd-El-Khalick, \& Lederman, 2000; Lederman, Schwartz, AbdEl-Khalick, \& Bell, 2001; Moss et al., 2001). Akerson et al. (2000) speculate that this is because the subtleties of the subjective and sociocultural influences on scientific 
practice are impossible to capture in a short course (in their case, a course designed for preservice teachers). We contend that it is also a consequence of uncertainty about intended learning outcomes in this particular NOS domain, the inadequacy of assessment procedures for capturing student understanding, and the pervasiveness and power of the images of science and scientists acquired through informal learning channels. A construct such as "the social and cultural embeddedness of scientific knowledge", the expression used by Lederman et al., can be interpreted in a number of ways: (1) scientific knowledge impacts on society, in the sense that it changes how we think and the ways in which we live; (2) social, cultural, economic and, political forces determine the priorities for scientific investigation and its associated technological development; (3) scientific knowledge is socially constructed and, therefore, reflects the experiences, beliefs, interests, values and attitudes of those who produce it, (4) there are distinctive "sciences”, such as African science, First Nations science and Islamic science, each of which can lay claims to provide a satisfactory, culturally-based explanation of phenomena and events in the natural world.

With regard to social interactions of scientists within the scientific community, Robert Merton’s classic book, The Sociology of Science, identifies four “functional norms" or "institutional imperatives" that, he claims, govern the practice of science and the behaviour of individual scientists, whether or not they are aware of it (Merton, 1973 [5])5. Not only do these norms constitute the most effective and efficient way of generating new scientific knowledge, they also provide a set of “moral imperatives” that serves to ensure good and proper conduct.

- Universalism - science is universal (i.e., its validity is independent of the context in which it is generated) because evaluation of knowledge claims in science uses objective, rational and impersonal criteria rather than criteria based on personal, 
national or political interests, and is independent of the reputation of the particular scientist or scientists involved.

- Communality - science is a cooperative endeavour and the knowledge it generates is publicly owned. Scientists are required to act "in the common good", avoid secrecy and publish their findings and conclusions so that all scientists may use and build upon the work of others.

- Disinterestedness - science is a search for truth simply for its own sake, free from political or economic motivation or strictures, and with no vested interest in the outcome. Because attempts to exploit the ignorance or credulity of non-scientists or to fabricate results in pursuit of commercial or personal gain are strictly outside the code of approved scientific conduct, scientists have traditionally enjoyed a good reputation for ethical behaviour.

- Organized scepticism - all scientific knowledge, together with the methods by which it is produced, is subject to rigorous scrutiny by the community in conformity with clearly established procedures for judging such matters as methodological appropriateness, chain of argument from data to conclusions, and testability. The "emotional neutrality" of these procedures ensures that all knowledge claims are treated similarly, regardless of their origin.

Subsequently, Barber (1962) proposed two additional norms:

- Rationality - science uses rational methods to generate and validate its claims to knowledge.

- Emotional neutrality - scientists are not so committed to an existing theory or procedure that they will decline to reject it or adopt an alternative when empirical evidence points to it. 
A number of sociologists of science have argued that the so-called "Mertonian norms" of scientific conduct do not guide practice; rather, they are used retrospectively by scientists to dignify what they have done, and to impress nonscientists. Mitroff (1974), for example, suggests that the "emotional neutrality" of organized scepticism is frequently over-ruled by the 'emotional commitment' of scientists struggling to overcome difficulties and setbacks. Indeed, he postulates a counter-norm for each of the norms listed above.

- Particularism - the personal or professional attributes of the researcher, and the status of the institution, are frequently taken into account in the evaluation of scientific contributions.

- Solitariness - ownership and control of distribution of scientific knowledge reside with the individual scientist (or group) who produced it. On occasions results are withheld until a patent has been secured or delayed until their announcement will have greater impact.

- Interestedness - many scientists have personal agendas for engaging in particular research and may have a vested interest in the outcomes - even more so when research is funded by commercial organizations.

- Exercise of judgement - the expert opinion of experienced scientists plays a prominent role in the evaluation of knowledge claims. Moreover, the research of newcomers is subject to much more rigorous checks than the work of established scientists.

- Non-rationality - scientists do not always act in a fully functional manner and scientific advances can result from non-rational as well as rational actions. 
- Emotional commitment - commitment to a theory is essential for its advancement; disinterest leads to stagnation. On occasions, however, commitment in spite of substantial contrary evidence becomes unreasonable.

Teachers wishing to promote an authentic view of science, scientists and scientific practice need some clear guidance on the extent to which these norms and counternorms are evident in authentic, contemporary practice (science-in-the-making). The research described in this paper sought the views of scientists on these matters. Whatever stance is adopted on this particular NOS dimension, it is abundantly clear that curriculum coverage amounting to one or two brief examples will not achieve the understanding we seek, nor serve to dispel stereotyped, mistaken or confused views of science acquired elsewhere. Our belief that detailed and richly textured case studies (both contemporary and historical) may do so was the rationale underpinning our decision to gather information from practising scientists on the ways in which they conduct their day-to-day research activities, and to weave these insights into case studies of contemporary scientific practice. Wong and Hodson (2009a) has already reported on what scientists told us about methods of scientific investigation, and the role and status of scientific knowledge. This paper reports on what these same scientists told us about the social dimensions of scientific practice.

\section{PARTICIPATING SCIENTISTS}

Convenient and purposive sampling was adopted in this study. The first author, who was formerly an active scientist with direct and indirect connection with many wellestablished scientists in various fields, invited a number of experienced scientists with an international reputation for research productivity and eminence in the field to participate in the study. Fourteen scientists accepted our invitation ${ }^{6}$. Their research 
careers at the time of the study ranged from 10 to 47 years. The participating scientists are located in different parts of the world: United States, United Kingdom, Switzerland, New Zealand and China. Eleven have worked in more than one country, and collectively their experience spans a wide range of sociocultural settings. All are currently working in universities or government research institutes. The selection criterion of research productivity and international eminence, together with our commitment to ensuring a wide disciplinary sample, resulted in 13 of the participating scientists being male. Although a more equitable gender balance would have been desirable, we recognize that this imbalance reflects the reality of senior positions in many prestigious research establishments. Details are summarized in Table 1.

Table 1 about here

It should be noted that our research was not intended to produce a sample of scientists' views representative of all sociocultural locations, all disciplines and all types of research establishments, or to seek commonalities and differences in NOS views that reflect subject specialization. Rather, we were interested in the extent to which those working at the "cutting edge", in whatever field, hold views that are similar or dissimilar to the views currently being promoted in the science education literature, and in what ways they might support or challenge the views commonly promoted via school science textbooks. At the heart of this latter concern was speculation that advances in knowledge and procedures in rapidly growing fields like molecular biology, stem cell research and materials science might already have rendered curriculum and 
textbook images of science obsolete or incomplete. Hence our inclusion of several scientists active in these research fields.

\section{DATA COLLECTION}

A modified version of the open-ended questionnaire, Views of Nature of Science Questionnaire (VNOS-C), developed by Lederman et al. (2002), was chosen as the primary data-gathering instrument. VNOS-C is an open-ended instrument, which in conjunction with individual interviews can serve as a meaningful probe of respondents' NOS views. Rather than assessing whether the scientists possess what some science educators have termed "adequate views" about science (with reference to the consensual list of NOS items), the modified questionnaire aimed to elicit as much detail as possible about scientists' actual views on NOS and, more importantly, to act as a prompt for them to talk about the ways in which their views are exemplified in their current work practices. The original 10 questions of VNOS-C were slightly rephrased to achieve these purposes. Because the 10 questions of VNOS-C only sought NOS views related to the nature of scientific knowledge, we included additional questions designed to ascertain scientists' views on the characteristics of scientific inquiries and social interactions within and beyond the scientific community. We were especially interested to learn scientists’ views on: (1) the ways in which scientists design and conduct their inquiries; (2) the social, political and economic constraints faced by scientists; and (3) the processes by which scientific knowledge is constructed and validated. We also asked about the desirability of including explicit teaching of NOS in the school science curriculum, particularly in relation to the inevitable reduction in time available for other parts of the curriculum (see Wong \& Hodson, 2009a). The questionnaire was sent to the scientists immediately 
after their acceptance of our invitation to participate, several weeks before the interview. This allowed them adequate time to relate their research experience and other relevant experience to their views on NOS, and created an opportunity for them to reflect upon their views. At the beginning of the interview, we reiterated that our principal goal was the nature of science as reflected in their science practice. Participants were encouraged to share as much detail as possible of the features of scientific practice related to and beyond the areas covered in the questionnaire. Interestingly, many scientists commented during interview that they had never seriously pondered these questions before participating in our study. In-depth interviews of 90-180 minutes duration were conducted in order to elaborate on scientists' questionnaire responses and furnish detailed descriptions of individual views on science and day-to-day scientific practices. Face-to-face interviews were conducted with nine scientists; interviews with the remaining five were conducted by telephone. Some later clarification of data was carried out via email correspondence and follow-up telephone calls. The face-to-face interviews were video-taped and the phone interviews were audio-taped. The data were subsequently transcribed for analysis. The final transcriptions were sent to all participating scientists for confirmation of an accurate record of the interview.

Of course, there is no guarantee that scientists are always truthful in their selfreports of daily practice, though we did ensure that all participants appreciated that our research purpose was focused very directly on actual scientific practice and how that might resemble or differ from textbook descriptions. Most of the scientists expressed strong support for this endeavour and were keen to assist us, so we have good grounds for believing that their descriptions were faithful to their actual practice. 


\section{DATA ANALYSIS}

Regular meeting were held between the authors to identify, discuss and reach agreement on the NOS aspects embedded in the responses to the questionnaire and in the interviews with scientists. The NOS items were first cross-referenced to the list of NOS elements generated from curriculum standards documents by McComas and Olson (1998), though one or two additional elements were needed to ensure full acknowledgement of the range of NOS issues raised by the scientists. Full agreement of authors on the finalized list was achieved with regard to eight prominent categories: (1) methods of scientific investigation (including the role of hypothesis and the design of experiments); (2) the significance of theory in scientific inquiry (including thoughts on observation and inference); (3) the tentative nature of science (including warrant for belief and the status of laws and theories); (4) creativity in science (before, during and after data collection); (5) the external social context - that is, the social, political, economic and cultural influences on science, and the impact of science on society and environment; (6) research funding issues, academic freedom and ethics; (7) collaboration and competition; and (8) peer review. For the purposes of a previous paper (Wong \& Hodson, 2009a), data in the first four of these categories were collapsed into two major themes: (i) methods of scientific investigation and (ii) the role and status of scientific knowledge. For this paper, data in categories 5 to 8 are reported under the remaining major theme: science as a social practice.

\section{WHAT SCIENTISTS SAID ABOUT SCIENCE AS A SOCIAL}

\section{PRACTICE}

The scientists made numerous remarks about science as a social practice. First, they observed that social, economic, political and moral-ethical factors determine priorities 
for scientific inquiry and development. Second, they acknowledged that most scientists work as members of a team, regardless of whether they are employed in universities, research institutes or industry. They reminded us that scientists are dependent on one another for the intellectual and technical resources with which they work. In other words, existing theoretical and procedural knowledge, investigative techniques, laboratory apparatus and instruments, and so on, collectively constitute the research context within and upon which further progress is based. Furthermore, the rules of scientific procedure and the legitimacy of the 'product' are determined by the community of practitioners. The wider community of scientists determines what counts as acceptable scientific practice and exercises strict control over what is admitted to the corpus of accepted knowledge through its system of peer review. While these views are, in general, unsurprising and largely in agreement with descriptions of science expressed by science educators, there is much of interest in the detail of the scientists' remarks that teachers can share in their classrooms or use in designing case studies of authentic practice.

\section{The External Social Context}

There were frequent references to the social and environmental impact of scientific change and technological development, and universal recognition that, to some extent, science and technology are socioculturally determined. On the latter issue, all the scientists recognized that sociocultural and economic factors determine the kind of research that gets done (not least in respect of funding priorities, as described in the next section).

Most scientists acknowledged that intuition and aesthetics can play a substantial role in theory building; all subscribed to the view that existing knowledge 
and expectations impact on observation and experimental design (see Wong \& Hodson, 2009a); a few acknowledged that this could also play a role in data interpretation. The scientists were unanimous in acknowledging that scientific knowledge is created, sustained, transmitted and modified through social processes. In other words, it is sociohistorically situated. Scientific theories are human constructions that depend for their existence on human agents and their commitment to develop such theories, explore the rationality and adequacy of theories, discover robust facts about the natural world, manipulate nature, and so on. Being part of the cultural resources produced by human beings, science is not immune from other cultural and ideological influences. None of the scientists ruled out the influence of ideology, intuition, luck, greed, personal interests, publishing pressures, and the like, on what science is pursued, produced, accepted and published. However, it was made abundantly clear by these scientists that recognizing science as a social activity in these senses, and acknowledging that its methods and procedures were established by people and are sustained by authority and custom, is not to say that the scientific knowledge produced is merely a social construct, and could be otherwise. Indeed, the view that science is universal and is 'true' everywhere in the world was shared by all the participating scientists, at least in relation to established scientific knowledge. "Science gives the same results no matter where you do the test, when you do the test or how long ago you did the test" (Cancer Biologist). "The laws or theories we suggest are true everywhere and true at any time. Newton's Laws apply not just now, but also in the Qing Dynasty, Ming Dynasty or on Mars.” (Astrophysicist).

A correct result, correct experimental result, can always be reproduced by other people under different conditions... and has nothing to do with time. It's valid today, must be valid tomorrow, must be valid the next day. Nothing to do with space; if it's valid in Hong Kong, it will be valid in Beijing, valid in Washington. (Experimental High Energy Physicist) 
In considering why the scientific community is able to reach agreement on what scientific knowledge to accept, when debate in other subject areas rarely reaches consensus, these scientists claim that it is because the knowledge generated by scientific inquiry approaches a true account of the universe. Agreement has something to do with the constraints on knowledge imposed by Nature itself.

Different interpretations may be a good thing because every mind is only a subset of the whole existing knowledge... and everyone's subset is different. Using the same observations or data... [scientists] with different subsets will generate different explanations... it is the combination of all the interpretations that, after many years, may finally lead to the real picture. (Molecular Biologist)

None of these scientists claimed that there is only one conceivable representation of the world, or that we can know what the world is like independently of our conceptual structures. But this is not to say that the world is merely a construct of the human mind, that our knowledge is purely arbitrary, or that individuals are free to make unique interpretations of sense data or to fabricate any world that happens to suit them. Admitting that observation is theory-dependent and that theories are human creations does not mean that science loses its objectivity. Admitting that theoretical explanations could be different does not reduce science to mere fashion, prejudice or social convention. Science cannot be anything that important scientists choose to say it is. The world does limit our scope for theoretical speculation.

A number of our respondents commented on the impact of science on all aspects of contemporary life. For example, the experimental high energy physicist gave several examples of the ways in which 'frontier science' has changed daily life quite radically.

A hundred years ago we talked about mechanics, thermodynamics and optics. Now they are used in aircraft, steam engines and television. In the 30s, the frontier science was atomic physics. Now it's used in superconductivity, lasers, transistors, semiconductors. Almost all daily industries 
in every country come from studies we considered frontier science in the 1930s and 1920s. In the 1940s, the frontier science was nuclear physics.

Now it is used in energy and defence.

Funding Issues - priorities, ethics and fraud

Funding issues were frequently mentioned, both on the questionnaire and in the interview, as found by Abrams and Wandersee (1995) in their study of scientists.

Most commented that the direction of contemporary research is largely governed by political decisions based on social and economic demands, which is particularly problematic for pure science research with no immediate or apparent technological applications. "Funding agencies determine to a large extent when, where, how much and what kind of research is done” (Experimental Particle Physicist).

The theoretical high energy and experimental particle physicists bemoaned the reduced interest in their field and reduced research funding from government as a direct consequence of their research not being immediately applicable, in contrast to research in fields such as materials science, molecular biology and medicine. However, even those working in the privileged research fields that are more attractive to funding from the government expressed concern about limited flexibility in the choice of research topics and the constraints of limited funding on their abilities to be adequately competitive. "The social, ethical, cultural and political interests of the funding bodies may affect the selection of target and strategy of our research, so that scientists cannot do what they want to do” (Molecular Biologist).

It really costs lots of resources to do scientific research... The reality is there are many things that cannot be achieved without money... A large portion of the research grants we obtain is spent on equipment. Lots of money is spent on recruiting staff, too, especially for experimental research... There 
are lots of manpower, equipment and resources involved in the process. (Biochemist)

If our research team does not have the high-throughput [genomic] sequencers, there is no way we can compete with other top research groups... Without them , even if we have brilliant ideas, we simply can't try them out in time... If the speed of data generation is not quick enough, it would be history at the time of data completion...Nowadays, if your lab is not wellfunded enough, it is very difficult to win. (Medical Geneticist)

A number of scientists commented that restricting funding to "readily applicable research" has led to imbalance among the sciences and the serious neglect of fundamental research - research that may, in subsequent years, turn out to have considerable practical application. As the solid state physicist pointed out, the computer did not develop from research directed towards social and economic needs; it was, he said, "fundamental research that got us there". What is needed, he said, is a balance between directed and undirected research. Even in the biological sciences, social factors lead to emphasis on particular research topics and neglect of others. "Science does reflect social and cultural values. For example, if you read British medical journals, e.g., the Lancet, diseases that affect the Western world are usually featured more frequently than those that predominantly affect non-Western countries” (Medical Geneticist).

The biochemist, whose current research focuses on finding a biochemical means to fight liver cancer, told us that his research team had solved some of the funding problems by establishing a biotechnology company, with start-up capital provided by an investor. If a successful treatment is developed, the return on the investor's outlay from sale of pharmaceutical products will be considerable. While this may be a solution for him, several scientists commented that even research areas of huge potential application and financial reward are restricted because of ethical concerns. Predictably, the stem cell biologist reminded us that his research area and cloning research, are currently the focus 
of vigorous debate within the wider society about the desirability of further advances. In a lengthy statement, the medical geneticist pointed to what he considers to be an ethical confusion surrounding the banning of stem cell research in the United States.

In stem cell research, some of the cells have to be extracted from embryos, and after this, the embryos will die... Many people in the United States have abortions... then the embryo also dies. Why is there a double standard? On the one hand, it doesn't allow the experiment, but on the other hand it allows abortion... We now have the technique to take out an egg, remove the nucleus from the egg, get a cell from your body, get the nucleus from your cell and put it into the egg, and create an embryo. Would you treat this as a real embryo? If you don't consider this a real embryo, then the experiment doesn't destroy an embryo. But some people have reservations about it because the so-called embryo is exactly the way Dolly (the sheep) was cloned. If I allow the embryo to develop further... it has the potential to become a human. Yet it isn't a human. If you extend the argument too much, you might have to protect every egg lost during a woman's menstruation, and every sperm - as they all have the potential to become a human. So... should some machines and treatments not be used any more? For example, birth control methods such as IUDs, inserted into the uterus to prevent the embryo from implanting. (Medical Geneticist)

In our view, this is exactly the kind of ethical questions that students in school science lessons should be confronting. The biochemist shared his views on patent-related ethical, financial and political issues based on his own experience in applications for patents.

It [patenting] has pros and cons...In the past, many scientists, particularly the basic researchers didn't like the idea of having a patent as they believed that knowledge should be available to anyone and anywhere... Nowadays, most countries, including developing ones, see the importance and values of it and have policies to support the scientists in academic and research institutes to apply for it. The potential of huge financial return has attracted investors and resulted in accelerated progress in science. (Biochemist)

He then moved on to share some typical considerations in one of his research areas: production of drugs.

For the development of drugs, there are a lot of factors to be considered...Is the disease common? Are there similar drugs targeting a different chemical pathway available? Is it a disease of the rich [e.g. heart disease, obesity]? Is it a disease of the poor? If it's the latter, a drug is unlikely to be developed as they [investors] can't recoup the cost. (Biochemist) 
Such considerations are inevitably intertwined with more intricate moral-ethical issues.

The medical geneticist also shared some "benefits" resulting from close connection with a biotech company. He commented that his research on prenatal diagnosis has been accelerated through the support of the biotech company which has purchased many of the patents generated from his research group.

Getting research funding from ABC company [pseudonym of the biotech company] is much quicker and more straightforward than applying for government funding through our Research Grant Council... [For government funding] you need to spend time to write a detailed research proposal in the annual grant application game and wait for a whole year to know if your grant application is successful or not. Worse still, the proposal may fall into the hands of keen competitors searching for breakthrough in the same field as yours. I am now more cautious and don't put in the most innovative idea in the annual grant application to avoid having the ideas pinched by other competing research groups. You know, nasty acts are not uncommon...

If I get an ultra good idea, I will give a call to ABC...they make a quick decision... If they see a potential valuable patent coming out from our idea, they prefer funding us for trying the idea to risking the idea being "disseminated" to competitors who may attempt to play the game unfairly. (Medical Geneticist)

Unfair play and scientific misconduct have sometimes brought disgrace to the scientific community. It was widely acknowledged by these scientists that the highly competitive funding situation has driven some scientists to commit scientific fraud in reporting their findings - a point made by some of the scientists in the study by Monhardt, Tillotson, and Veronesi (1999). Both the materials scientist and the astrophysicist mentioned the Bell Laboratories incident in which Jan Hendrick Schön fabricated impressive experimental results that took the scientific world so much by surprise that they were initially regarded, by many experts, as worthy of a Nobel Prize (see Service, 2002, 2003). However, all the participating scientists expressed the view that the requirement for scientific findings to be replicable under the same experimental conditions will eventually uncover such frauds, and all were keen to distinguish errors 
and misjudgements (both of which are considered inevitable) from conscious and deliberate attempts to mislead. Between the extremes of unintentional/unavoidable error (frequently described as "honest mistakes") and deliberate fabrication or misrepresentation of results (fraud), there is a substantial 'grey area' that reflects incompetence, luck and/or undue haste to publish. Some of our respondents were less than charitable about those 'offences' because, they said, they reflect badly on the scientific community as a whole.

\section{Collaboration and Competition}

All the participating scientists reported that they collaborate extensively, both within their own field and across disciplines, and consider such collaboration essential to speeding up knowledge generation, providing the range of expertise necessary for conducting complex, multi-faceted investigations, and extending their own interests and expertise. As the scale and breadth of research expands, and the complexity and multi-dimensionality of the problem under investigation increases, collaboration of experts in a range of disciplines is increasingly necessary.

[Collaboration is] very important, especially nowadays when we need multiple techniques from different fields to answer big questions. For example, in the recent SARS outbreak, we needed clinicians to collect samples, geneticists to do the DNA sequencing, epidemiologists to do the mathematical modelling and microbiologists to grow the virus. (Medical Geneticist)

The interviews with scientists gave us lots of confirmation that contemporary science is a complex patchwork of interacting and overlapping microcultures, each with its own knowledge, techniques, skills, language, interests, conventions and attitudes. 
As a modern scientist, I need to cooperate with many helpers and experts. It is very different from the old style scientist like Albert Einstein. Organization, coordination and compatibility among teammates are critical in modern research... No laboratory can master all techniques in a particular field. For example, my laboratory has extensive experience in DNA sequencing and protein-protein interaction study. If the project that I want to pursue involves protein purification, I recruit collaborators who are expert in this area instead of learning how to purify a protein - unless I shall be using this technique very frequently in the future or there are not many competitors interested in the project, so that I can afford to spend a lot of time learning the technique. Besides the complement of techniques, collaboration can also recruit more brilliant minds to think about the problem, sometimes maybe in a totally different dimension, if they are not working in the same field. I believe that every scientist has some blind spots and the comments and suggestions from our collaborators are the best treatment for such defects. (Molecular Biologist)

While many scientists talked about the need to establish a 'critical mass' of colleagues working on a particular problem or investigation, several commented that large teams frequently create management problems that distract senior scientists from scientific matters. Large teams reduce individual freedom and flexibility because of the need to reach consensus, which, of course, is not always easy. Large teams can easily lose focus because each member is inclined to pursue an individual agenda. Another concern is that working in large groups does not always provide the same level of satisfaction as working in small groups or working alone.

When my students work on a gene, student A works on one part, student B works on another part, and so on... It's like a factory... You cannot enjoy the whole process from the start to the end... In the old days, cobblers were so happy to have a good occupation from cutting leather to making the whole pair of shoes. It's so nice and satisfying when the shoes are put on the feet. Now there is nearly no satisfaction. (Molecular Biologist)

Conversation with all the participating scientists touched at some point on the topic of competition. The molecular biologist pointed out that competition acts as a spur to progress; it speeds up the pace of theoretical and procedural development and makes better use of limited financial resources by "getting rid of the weak and keeping the strong”. As the cancer biologist remarked, “without competition, people would be lazy”. 
But competition can also lead to unnecessary duplication of research efforts and the publication of incomplete studies. “Competition may also waste a lot of effort, or even funding, because a large number of groups may work on a hot topic simultaneously” (Molecular Biologist).

Perhaps the most obvious disadvantage of competition is that cooperation and the pooling of data and expertise is ruled out. A number of scientists also commented on the personal stress created by the increasingly competitive nature of scientific research.

It (competition) generates a very stressful environment for scientists so that sometimes they cannot enjoy the satisfaction from discovery because they try to compare with each other (e.g., amount of research funding, number and impact factor of papers they have published). (Virologist)

In startling contrast to the view of the Director of Research Initiatives that competition "keeps the field honest and exposes flaws and oversights in thinking”, the theoretical high energy physicist observed that competition for research funding inevitably leads to scientists overstating their case or making premature claims. If they are to obtain research funding, he said, "scientists have to gamble... on what they believe to be true. How can they obtain funding if they don't claim that the theory is true and correct?” Other negative consequences of the stressful environment of fierce competition for research funding were mentioned, including the tactic of trying to mislead competitors. "Other nasty actions including grasping results from other research groups using illegal or unethical means, misleading other research groups by providing wrong messages” (Molecular Biologist).

The cancer biologist mentioned a regrettably all-too-common tactic of releasing part of the research findings in support of an alternative explanation/theory to the main thrust of the investigation in a deliberate attempt to mislead or distract 
competitors. The molecular biologist told us about an episode he now regards as a deliberate and coolly calculated move to delay his research and use up valuable research materials. He had followed advice from another scientist concerning a new and supposedly robust laboratory technique that eventually, after months of wasted effort, proved to be useless. Interestingly, this scientist also remarked that with the rapid development of laboratory techniques that were unknown when some senior scholars first began their careers, many scientists are now increasingly dependent on the support of research assistants, who may be tempted to manipulate or even fabricate data in order to impress the project leader.

Several of the scientists interviewed in connection with SARS research commented that scientists are constantly "competing” with all manner of constraints, lack of time and limited resources, and with other research groups working on similar projects. The following is illustrative of this view: “Competition isn't just with other teams but also with time... The fact that science improves so quickly is all because scientists compete with each other, with time... and their own ego".

Peer review - issues of status, bias and self interest,

A key aspect of the social dimension of scientific practice concerns the validation and acceptance/rejection procedures for scientific discoveries. Knowledge claims have to be argued according to the 'rules of the game' laid down by the community of scientists and have to be expressed in a language and form determined by the community; an individual scientist's confidence in the significance of her/his work is insufficient to establish it as part of the body of knowledge; it must withstand critical scrutiny by the community by whatever means the community decides is appropriate.

We need to present our ideas in the form of a paper which contains some standard elements, such as title, abstract, introduction, scientific methods, 
results, conclusion and lots of references. This is the rule of the game and we have to follow it. (Biochemist)

There was wide agreement among the scientists that peer review safeguards the quality of publications and underpins the reliability of data and the validity of knowledge claims. Five of the scientists commented that (i) peer review is reasonably fair, and (ii) there is no fairer alternative.

An article or a piece of scientific work is usually peer-reviewed by several people with expertise in the field to determine whether the work is good and sensible enough to be published. The consensual peer review comments from these individuals should provide fairness. (Cancer Biologist)

However, the other nine scientists expressed reservations about the process. The principal concern is that the intense pressure to publish in the top journals has created a situation in which many scientists send every one of their research papers to an elite journal, even though many of them may be better located elsewhere. Consequently, editors of these journals report increasing numbers of rejections, appeals and complaints (McCook, 2006), and scientists report increasing dissatisfaction. According to the molecular biologist, this situation has led some scientists to make special efforts to cultivate friendships with journal editors (because it is hard to reject a paper submitted by a friend) and to use what might be termed 'tactical referencing' (because reviewers are less likely to reject a paper that includes a favourable citation of their own work).

Several scientists commented that the editorial policy of some journals seems to be driven by what may be best described as 'intellectual fashion'. Several scientists stated that editors are sometimes misled by exaggerated results, unwarranted conclusions and dubious claims about the applicability of findings, and that reviewers tend to write more favourable reports on studies with statistically significant results. Also, if it is true, as most of the respondents asserted, that publication is easier when scientists are theoretically conformist, in the sense of adhering to current theory, it 
follows that it is very difficult to make major theoretical breakthroughs. The theoretical high energy physicist talked about the difficulty of "breaking out of the confines of a theoretical framework" and accepting the unexpected: “we need to have genius to recognize these patterns, to jump over the framework, and to think of new ideas”. Somewhat paradoxically, he remarked that on occasions, "the odder and stranger the theory is, the easier it can be published”, lending further support to an observation common within this group of scientists that scientific practice and the response of the community to non-standard findings can be unpredictable, highly idiosyncratic and context-specific - a significant counterview to the textbook account of totally rational and objective appraisal.

Several scientists observed that human nature sometimes results in bias and can precipitate unjust decisions on an article. As the stem cell biologist remarked, "scientific publication is a human activity. It is always affected by all kinds of social factors.” The theoretical high energy physicist remarked that the lengthy review time (never less than 3 months, and sometimes as long as two-three years) is a major hindrance to progress. He even suggested that, from time to time, the review process is cynically exploited by competitors seeking to gain an advantage: "It may be that the reviewer is your competitor and somehow he tries to delay publication, prevent your paper from being published, or even steals the idea from your paper for his own research” (Theoretical High Energy Physicist).

We found evidence of an interesting disciplinary-related variation: very different degrees of tolerance about the duration of review process between traditional theoretical scientific research and research in some fast-moving fields. For example, the lengthy review process described by the theoretical high energy physicist is not common or even permissible in the rapidly growing field of molecular biology. As the medical 
geneticist commented, "Normally, we would be asked to review a manuscript within weeks. If the findings cannot be published within months, it's history.” This contrasting experience of the review process is further confirmation of the intense competition associated with the drive to be first to announce a new finding.

All scientists commented that considerations relating to both an individual's track record and connections to other researchers, and institutional prestige, can compromise the fairness of the system, with some expressing major concerns about the process. "Institutional prestige and individual prestige directly affect the probability of publication. The rich get richer (Director of Research Initiatives).

We were told that some journals put so much emphasis on the senior author's publication record that it is difficult for newcomers to enter the field. The cancer biologist even asserted that this is a deliberate tactic by some senior scholars to reduce competition for scarce research funding by excluding potential competitors. When the scientists were asked to describe how they assess the significance of a piece of research when they act as a reviewer, several admitted that they also fall into the trap of prestigeoriented bias. The molecular biologist even gave the following analogy:

Here... [pointing his finger to a paper on his desk] I'm reviewing a paper... I'll look for the country... which university it is from... see if it's reliable ... It's just like depositing money; we'll choose a reliable bank instead of putting money in any bank on the street...

He was frank in his admission that because his research group is not located in one of the top prestigious institutions, with a high reputation for the quality of its work, it is sometimes disadvantaged in the peer review process. However, he has developed a positive way of looking at the matter:

You know, the Harvard laboratory has taken several decades to have their laboratory well established...As scientists, sometimes we need to be very humble and know our limitations. We, not being Harvard, have to be gradually lifting our standard, initially working towards the 5-point 
journals [He is referring to the impact factor of a journal: the higher the factor the more prestigious the journal and the greater the competition for publication] and later challenge ourselves to publish in some 7-point journals, and so on ...I think that this is the correct attitude that we should hold when we're facing such problems [bias due to institutional prestige]. Instead of feeling gutted...this is, in fact, the reality and we should not regard it as a pressure but a driving force, and a healthy one.

Concern was expressed more than once that academia seems increasingly to place a higher value on the quality of the journals in which a paper is published than on the quality of the data itself. In many universities and research establishments, scientists are judged by how many papers they have published in top-tier journals; the more publications scientists accumulate, the more likely they are to gain promotion and to receive research funding. The theoretical high energy physicist said that the situation could be improved considerably by making more use of the Internet. One option is for scientists to make their work freely available to others. Another option, strongly supported by the medical geneticist, involves the notion of 'open publishing': editors post papers on the Internet and issue an open invitation to other scientists to review the paper, debate the results and conclusions, contribute additional or contradictory data, and so on. Allowing everyone and anyone to read the exchanges between authors and respondents would democratize science and speed up progress immensely. In a sense, it would recreate for everyone the experience of attending a research conference. Because everything is so public there would be in-built guarantees of proper care and attention on the part of reviewers. After a year or so, the journal editor could choose to publish the papers in print format. In the meantime, papers could be used and cited in the same way as conventionally published material.

The cancer biologist made some interesting points about publication of negative results. First, negative results help us to build a fuller picture because they exclude certain factors. Second, publication of negative results saves time and effort because 
other scientists are warned against engaging in fruitless experiments. For this very reason, there is an ethical obligation to disclose negative results and to inform others about failed trials and experiments. The theoretical high energy physicist said that such disclosure is better handled at the informal level: scientists should inform others working in the field directly, and as soon as possible, rather than publish (or attempt to publish) negative results in journals. Interestingly, the molecular biologist said that he searches the literature for negative results as an aid to experimental design: "If I can think of a better method, it's quite probable that the results would be different. So I'll give it a try”.

\section{What Can We Conclude?}

Our data provide some "from the horse's mouth" remarks that may enable teachers to 'put some flesh on the bones' of the otherwise bald assertion that science is socially and culturally embedded. We believe that Weinstein's four aspects of science, and the seemingly contradictory but co-existing Mertonian norms and Mitroff's counter-norms, could be readily appreciated by students if they are illustrated by vivid examples from authentic science practice.

As indicated earlier, all the participating scientists subscribe to the view that science is universal and holds everywhere in the world (what Merton (1973) termed “universalism”). This position has been described by Lederman et al. (2002) as a "naïve” view, associated with ignorance of the social and cultural embeddedness of science. Our data show that all the participating scientists are fully aware (sometimes uncomfortably so) of the influence of economic, political, social and cultural factors on the development of science (what Weinstein (2008) calls “science as culture”). Although the scientists identified some key issues related to funding for research that 
are specific to particular societies, and noted some differences in national priorities and culturally determined interests, they provided no evidence that science is conducted differently in different sociocultural contexts. This constitutes an additional sense in which our informants regard science as universal. From a science curriculum perspective it may be prudent to point out that several scholars have identified ways in which science may be conducted differently, for different purposes, and with different outcomes, when the sociocultural context changes. For example, Donna Haraway (1989) has shown how a group of women scientists successfully challenged the androcentric assumptions, language and theories of primatology and radically reshaped accounts and explanations constructed by earlier scientists (exclusively male) to explain primate behaviour and social organization, while Sardar (1989) and Loo (1996) have discussed the extent to which a distinctive Islamic science, with significantly different underlying value positions, can be discerned. It seems that culturally derived assumptions can accommodate and facilitate some conclusions and practices, while acting to oppose or exclude others. It follows that a strong case can be made for seeking greater diversity within the scientific community on the grounds that exposing science to the scrutiny of those with alternative viewpoints would increase the objectivity of research. As Helen Longino (1990) and Sandra Harding (1991) note, a scientific community with diverse contextual values will be more likely to recognize when the contextual values of an individual scientist have had negative influence on his/her research and more likely to take account of alternative perspectives on research priorities, investigative design, conclusions and publication of findings.

In common with scientists in the study reported by Schwartz and Lederman (2008), our informants expressed concern about funding issues, even suggesting that the priorities established by funding agencies sometimes curtail important lines of 
research (especially so-called 'Blue Skies' research) and may lead them to change their own research agendas. The molecular biologist commented that, in genomics research, scientists have to pretend to be engaged in hypothesis-driven research because funding bodies regard purely open-ended work as little more than "fishing expeditions”. But without these "fishing expeditions”, he said, potentially crucial information will be missed: “We won’t know the significance of any one piece of data if we don't have it all”. These influences on the kind of science we conduct and on the way in which it is conducted are largely ignored by science curricula and science textbooks. In our pursuit of critical scientific literacy we might consider presenting students with two key questions: "Who determines the extent and direction of research funding?” and “How are research priorities established?” Other questions might follow: “Should our priorities be different?” and “How can we intervene to reprioritize?”

Many school students harbour the view that new scientific results will automatically be published once they are generated; they are unaware that new knowledge claims have to undergo a stringent peer review process before publication. Indeed, this is an aspect of scientific practice on which school science textbooks are strangely silent. The goal of authenticity with respect to NOS demands consideration of the 'publications business', but not necessarily “warts and all”. Several scientists expressed their concern about letting school students realize that friendship, power, prestige and prejudice can play a role in appraisal, acceptance and rejection of scientific knowledge ${ }^{7}$. While the astrophysicist argued that secondary school students "should be told that scientists or researchers may make mistakes or frauds... some are fraudulent and some are decent”, most of the participating scientists hold views similar to those of Allchin (2004), and were concerned that too early an awareness of the reality of scientific practice might 
dissuade students from pursuing a career in science. Our view is that these problematic issues should be approached cautiously and in ways that take account of students' scientific understanding and emotional maturity.

Traditionally, textbooks portray scientists as working single-handedly to make great scientific discoveries (Allchin, 2003). The reality of scientific practice is often very different. Our data provide many illustrations of the need for scientists to collaborate, often with people in different disciplines. For example, the biochemist specializing in liver cancer works with an oncologist and a chemical engineer - the latter being responsible for converting test tube procedures to an industrial scale. Among the scientists we have interviewed there is a widespread and not unreasonable assumption that well-organized collaborative teams are better positioned to attract research funding and access scarce and expensive resources, and are more productive. Moreover, wealthy and prestigious research groups are better positioned to attract gifted scientists, further increasing their chances of generating breakthrough results. Our informants also told us that collaboration is not always "plain sailing"; there can be many difficulties and frustrations. Even a casual perusal of academic journals in science will reveal that the average number of authors per scientific article has increased steadily over the past 2030 years. Moreover, the average number of countries represented per article has also increased steadily - an involvement that has been aided by recent advances in ICT. Thus, no one author of a multi-authored paper can check all the work for herself/himself or be familiar with the details and nuances of all aspects of the work. Like workers on a production line, nobody has a complete overview; moreover, everyone has to compromise to some extent. This is the new political reality for scientists, and a far cry from the traditional picture of the dedicated lone figure patiently pushing back the frontiers of science. 
Competition is even less frequently mentioned in school science textbooks than collaboration, and is generally excluded from science education standards documents (McComas \& Olson, 1998). Rather, students are told that scientists readily share their findings with others. Interestingly, some of the scientists in our study went so far as to say that competition is the principal motivation for scientists. Sharing is not driven by altruistic motives, but by self-interest in the pursuit of enhanced reputation and increased funding. For example, the experimental high energy physicist commented that "in science there is only number one, there is no number two... Number two, number three and number ten are the same”. It is understandable that teachers may feel particularly hesitant about venturing into the uncertain territory that deals with the "ugly side" of competition among scientists and the "sharp practices" in which scientists sometimes engage. They may be hesitant to undermine or destroy the heroic scientist image that students gain from movies and storybooks; they may worry that disillusioned students will turn away from science. However, the failure to describe these two major social interactions among scientists (cooperation and competition) only serves to strengthen the stereotypic image that scientists are isolated, solitary, remote and divorced from normal human interaction (Milne, 1998). Our view is that teachers can solve this dilemma by revealing "both sides of the coin" of competition. Although there are occasional negative incidents, the scientists in this study generally regard fair competition in just the same positive and advantageous light as collaboration.

Complementary collaboration, good communication and candid discussion between close collaborators will bring out the best in science. Keen competition in the same field will hasten science to progress much faster and finer, if it is competition in a fair and healthy manner. (Cancer Biologist)

As Ford (2008) comments, even the immensely competitive business of arguing and debating the merits of rival knowledge claims is a form of collaboration, as the 
community collectively validates and accepts some claims and rejects or delays others. Indeed, it is this inter-subjective deliberation (competition and collaboration) that gives the scientific community confidence in its work and in the validity and reliability of the knowledge it generates. It gives us better science!

Perhaps teachers could use the occasional negative effects of competition in science to teach students about the proper way to do science and about the essential virtues of a good scientist. There is an ideal practice, or science as it should be, but sometimes practitioners fall short of these standards. Our view is that the words of the molecular biologist (quoted earlier) strike an appropriately balanced view for the curriculum: human frailties intervene, but they can act as an incentive for scientists. Our experience, reinforced by the views of these scientists, is that all scientists make mistakes from time to time - sometimes trivial and easily corrected; sometimes more serious and persistent, but eventually subject to correction. Every scientist, at some point in her/his career, may have to admit to being wrong. Steven Weinberg (1994) argues that this salutary experience for individual scientists is what gives the scientific community confidence in the security of its knowledge: "It is the scientists' experience of being forced by experimental data or mathematical demonstration to conclude that we have been wrong about something, that gives us a sense of the objective character of our work” (p.750). Ford (2008) comments that scientists are particularly adept at identifying the errors of their peers. First, because they are likely to be in competition with the scientist or group of scientists advancing the claim, they have a vested interest in finding flaws. Second, because they are deeply immersed in closely related conceptual and procedural issues they are likely to have encountered the same kinds of problems, collected the same kinds of evidence (though not always by the same means), and contemplated the same kinds of interpretations and 
arguments. Ford concludes, "it is hard to imagine anyone better suited to identify errors in a scientific argument than a scientist's peers” (p.409).

Of course, identifying and publicizing errors in the work of others sometimes requires a substantial measure of courage, as discussed by Wong, Hodson, Kwan, and Yung (2009b) in relation to research on SARS. Dr Frederick Leung, leader of the SARS research team at the University of Hong Kong, gives a fascinating insight into the dilemma faced by his team prior to disseminating their findings about the sequence of the SARS-coronovirus on the WHO network. The crucial point is that the Hong Kong team's data conflicted with data accumulated by the highly prestigious Centre for Disease Control and Prevention (CDC) in Atlanta, Georgia.

Around 10.00pm, it was the last base pair... my research students didn't know what to do... In the US sequence, the first base pair of the head was an "A", but ours started with a "T"... My students asked me if we should put an " $\mathrm{A}$ " or a "T". When that student asked me, I thought of one thing, this was one of the best chances for me to share with my students one of the important points, that is "data don't lie". I stopped everyone in the team from working and asked them what we should do as the CDC sequence started with an "A" and our started with a "T". No one answered, as Hong Kong students are usually shy... So I told them to take out all the raw data, and we not only did a duplicate or a triplicate... Over and over again, we found that it was a "T", so I said, "Do we still have any doubt about whether to put an " $\mathrm{A}$ " or a "T"?" And one student was really funny, he said, "Fred, CDC could not be wrong". And I said, "Well, I don't care much about whether CDC could be wrong or not, our research confirmed over and over again that we started with a " $T$ " instead of an " $A$ ", so we should enter a " $T$ " instead of an "A"” At about 11.30pm, we uploaded our sequence.

The episode graphically illustrates two important points: (1) claims made by prestigious research institutions are much more likely to be accepted by other scientists than claims emanating from elsewhere; (2) scientists need the honesty, confidence and courage to advance their own views rather than deferring to a supposed greater authority. It reinforces the view that the rationality of science and the trustworthiness of the knowledge it generates is located in (a) careful and critical 
experimentation, observation and argument, and (b) critical scrutiny of the procedures and products of the enterprise by other practitioners. It is a community-regulated and community-monitored rationality. Science is socially constructed through critical debate, and those involved in it have a commitment to maintain certain standards of debate. The consensus view among the scientists we have interviewed has much in common with Merton’s (1973) norm of “Communality”.

Of course, reviewers of papers submitted for publication usually have to trust the data that is presented. Notwithstanding the points made earlier about detection of errors by peers working in the same field, reviewers often do not have the time, opportunity or even the inclination to check data. To deal with this situation, Hardwig (1991) proposes the principle of testimony: "If A has good reasons to believe that B has good reasons to believe p, then A has good reasons to believe p” (p.697). In essence, he argues that A's good reasons depend on whether B can be regarded as truthful, competent and conscientious. Thus, the reviewer needs to evaluate the researcher's competence (with regard to the design and conduct of the inquiry and the quality of the analysis, interpretation and argument) and be vigilant for signs of vested interest. Indeed it is now a requirement of most scientific journals that authors of a paper have to declare any vested interest they may have related to the work presented in the paper. In short, it isn’t possible to draw a sharp distinction between evaluation of the research and evaluation of the trustworthiness of the researcher.

If it survives critical scrutiny by the community, using these public methods of evaluation and judgement, the knowledge item (model, theory, experimental procedure, instrumental technique, or whatever) becomes part of the written record of the scientific community and is made available to others. Because of this mechanism and the confidence that practitioners have in it, science is cumulative; current 
researchers utilize the knowledge generated by previous scientists and, in doing so, may develop it or discard it. Of course, the way in which the community of scientists exercises this public scrutiny at any one time is subject to a whole range of social, cultural, political and economic factors. For example, the likelihood of individual scientists being persuaded by a particular argument or influenced by particular evidence depends, in part, on their background knowledge, assumptions and values. The possibility that different perspectives will be brought to bear in the appraisal process is the reason for upholding the principle of academic equality and one of the guarantees of scientific objectivity. As noted earlier, it also constitutes a powerful argument for increased diversity within the scientific community.

Discussion of the ways in which the construction and validation of scientific knowledge are affected by the "thoroughly human nature of scientists” (to use Fuller's (1988) words) can be extended to influences outside the scientific community in order to show that science is not the value-free activity portrayed by most science curricula. If our concern is to present an authentic view of science to our students we should address the funding issue and its impact on the kind of scientific knowledge we generate. After all, as Young (1987) reminds us:

Science is not something in the sky, not a set of eternal truths waiting for discovery. Science is practice. There is no other science than the science that gets done. The science that exists is the record of the questions that it has occurred to scientists to ask, the proposals that get funded, the paths that get pursued... Nature 'answers' only the questions that get asked and pursued long enough to lead to results that enter the public domain. Whether or not they get answered, how far they get pursued, are matters for a given society, its educational system, its patronage system and its funding bodies. (pp.18-19).

Many of our respondents revealed a so-called elaborated or "informed view" of science-society interaction (Lederman et al., 2002) by reinforcing their views 
about the ways in which society impacts "the science that gets done” with comments on the impact of science on all aspects of contemporary life. For example, the medical geneticist commented: “Science knowledge often affects people’s decisions on lifestyle and habit” and it can sometimes change quite radically the ways in which people think and act. For example, the science of Galileo, Newton, Darwin and Einstein changed our perception of humanity's place in the universe and precipitated enormous changes in the way people address issues in politics, economics and history.

It is the complex nature of the interaction between science and society that we believe should be the vehicle for addressing NOS issues in the school science curriculum (Wong \& Hodson, 2009a). It is our intention to develop the descriptions of scientific practice provided by this group of well-established scientists and possibly beyond, with appropriate modification to suit the cognitive level of the students, into teaching resources to enhance and enrich understanding of NOS. What we are planning is an approach that emphasizes the discipline-specific and context-specific nature of scientific practice, as advocated by Rudolph (2000, 2003), Dagher and BouJaoude (2005) and Samarapungavan et al. (2006). Our first attempt to implement such a curriculum has focused on the recent SARS episode - a particularly rich and personally meaningful focus for students in Hong Kong (Wong et al., 2009b). Particular features of this case study include the shifting balance between cooperation and competition as the search for the nature of the SARS virus intensified, the key role of technology, hypothesis-driven versus open-ended data collection, reputation of researchers, influence of prior expectations on the design of the inquiries and the interpretation of data, and, of course, the sociocultural and economic dimensions. Several other case studies, emphasizing other elements of contemporary scientific practice, such as issues related to funding, research priorities, peer review processes and moral-ethical 
standards, are currently being developed from the detailed comments of the biochemist and medical geneticist. Their close collaboration with commercial companies has allowed us to observe many subtleties related to funding and moral-ethical issues. We acknowledge that the lack of participating scientists working for commercial companies may not have exposed us to a comprehensive picture of science, especially in relation to matters such as research funding, research priorities, decisions about pursuit of commercially unattractive drugs, treatments and diagnoses, and suppression of what might be called “inconvenient findings”. Future cases will address the often striking differences between the practices of scientists working in research institutes with commercial involvement and those without.

By drawing on some of the sociology of science literature, together with these 'from the horse's mouth' comments from scientists, we can debunk the idealized image of science as a fully rational, carefully articulated method for proceeding, in all circumstances, in a simple and direct fashion, and in a disinterested and value-free way, from observation to hypothesis to experimental test to accepted knowledge. Longbottom and Butler (1999) warn us that if we reject this traditional view of science and

...go along with those who deny that modern science provides a privileged view of the world... we fall into an abyss where skeptical postmodernists, who have lost faith in reason, dismiss all knowledge claims as equally arbitrary and assume the universe to be unreliable in its behavior and incapable of being understood” (1999, p.482).

We strenuously disagree. We believe that we can counter the stereotype of scientific practice very effectively with a balanced selection of ideas from the sociologists and anthropologists of science and still ensure that science is recognized as a rational, robust and extraordinarily productive enterprise. By using the comments of practising scientists as a further balance, we can retain the rationality of science and make the 
scientific enterprise appear exciting, interesting and accessible to students, even though we may reveal one or two less-than-savoury aspects of the day-to-day lives of scientists. The molecular biologist revealed that he shares our belief when he remarked that a case-based approach "conveys a sense of excitement through its emphasis on creativity and intellectual endeavour... it (also) teaches students not to believe everything they are told and to have the confidence to work things out for themselves”. As we argued in Wong \& Hodson (2009a), we can think of no better justification for the curriculum we are developing.

\section{ACKNOWLEDGEMENT}

The authors gratefully acknowledge the fourteen scientists who kindly devoted their precious time to be our informants.

\section{References}

Abd-El-Khalick, F., Bell, R.L. \& Lederman, N.G. (1998). The nature of science and instructional practice: Making the unnatural natural. Science Education, 82(4), 417-437.

Abd-El-Khalick, F. \& Lederman, N. G. (2000). Improving science teachers' conceptions of the nature of science: A critical review of the literature. International Journal of science Education, 22(7), 665-701.

Abrams, E. \& Wandersee, J.H. (1995). How does biological knowledge grow? A study of life scientists' research practices. Journal of Research in Science Teaching, 32(6), 649-663.

Aikenhead, G.S. (1973). The measurement of high school students' knowledge about science and scientists. Science Education, 57(4), 539-549. 
Aikenhead, G.S. (2005). Research into STS science education. Educación Quimica, 16(3), 384-397.

Aikenhead, G.S. (2006). Science education for everyday life: Evidence-based practice. New York: Teachers College Press.

Akerson, V.L., Abd-El-Khalick, F. \& Lederman, N.G. (2000). Influence of a reflective activity-based approach on elementary teachers’ conceptions of nature of science. Journal of Research in Science Teaching, 37(4), 295-317.

Allchin, D. (2003). Scientific myth-conceptions. Science Education, 87(3), 329-351.

Allchin, D. (2004). Should the sociology of science be rated X? Science Education, 88(6), 934-946.

Alters, B. J. (1997). Whose nature of science? Journal of Research in Science Teaching, 34(1), 39-55.

American Association for the Advancement of Science (AAAS) (1993). Benchmarks for scientific literacy. (New York: Oxford University Press).

Bell, R.L., Blair, L.M., Crawford, B.A., \& Lederman, N.G. (2003). Just do it? Impact of a science apprenticeship program on high school students' understandings of the nature of science and scientific inquiry. Journal of Research in Science Teaching, 40(5), 487-509.

Bencze, L., \& Hodson, D. (1999). Changing practice by changing practice: Toward more authentic science and science curriculum development, Journal of Research in Science Teaching, 36, 521-539.

Calabrese Barton, A. \& Yang, K. (2000) The case of Miguel and the culture of power in science. Journal of Research in Science Teaching, 37, 871-889.

Cobern, W.W. \& Loving, C.C. (2001). Defining 'science' in a multicultural world: Implications for science education. Science Education, 85, 50-67. 
Council of Ministers of Education, Canada (1997). Common framework of science learning outcomes. Toronto: CMEC Secretariat.

Dagher, Z. R. \& Boujaoude, S. (2005). Students' perceptions of the nature of evolutionary theory. Science Education, 89(3), 378-391.

Davson-Galle, P. (2008) Why compulsory science education should not include philosophy of science. Science \& Education, 17, 677-716.

Department of Education, Republic of South Africa (2002). Revised National Curriculum Statement for Grades 8-9 Schools. Pretoria: Department of Education.

Driver, R., Leach, J., Miller, A. \& Scott, P. (1996). Young Peoples Images of Science. Buckingham: Open University Press.

Elby, A. \& Hammer, D. (2001). On the substance of a sophisticated epistemology. Science Education, 85(5), 554-567.

Finson, K. D. (2002). Drawing a scientist: what we do and do not know after fifty years of drawing. School Science \& Mathematics, 102(7), 335-345.

Ford, M. (2008) Disciplinary authority and accountability in scientific practice and learning. Science Education, 92(3), 404-423.

Fuller, R. (1988). Social Epistemology. Bloomington, IN: Indiana University Press.

Gallagher, J.J. (1971). A broader base for science education. Science Education, 55, 329338.

Glasson, G. E. \& Bentley, M. L. (2000). Epistemological undercurrents in scientists' reporting of research to teachers. Science Education, 84(4), 469-485.

Good, R. \& Shymansky, J. (2001). Nature-of-science literacy in Benchmarks and Standards: Post-modern/relativist or modern/realist? Science \& Education, 10, 173-185. 
Goodrum, D., Hackling, M. \& Rennie, L. (2000). The Status and Quality of Teaching and Learning of Science in Australian Schools: A Research Report. Canberra: Department of Education, Training and Youth Affairs.

Haraway, D.J. (1989) Primate visions: Gender, race, and nature in the world of modern science. New York: Routledge.

Harding, S. (1991). Whose science? Whose knowledge? Thinking from women's lives. Ithaca, NY: Cornell University Press.

Hardwig, J. (1991) The role of trust in knowledge. Journal of Philosophy, 88, 693-708.

Helms, J.V. (1998) Science and/in the community: Context and goals in practical work. International Journal of Science Education, 20(6), 643-653.

Hodson, D. (1998). Science fiction: The continuing misrepresentation of science in the school curriculum. Curriculum Studies, 6(2), 191-216.

Hogan, K. \& Maglienti, M. (2001). Comparing the epistemological underpinnings of students' and scientists' reasoning about conclusions. Journal of Research in Science Teaching, 38(6), 663-687.

Irwin, A.R. (2000) Historical case studies: Teaching the nature of science in context. Science Education, 84(1), 5-26.

Labinger, J. A. (1995). Science as culture: A view from the Petri dish. Social Studies of Science, 25, 285-306.

Latour, B. (1987). Science in action: How to follow scientists and engineers through society. Cambridge, MA: Harvard University Press.

Laudan, L., Donovan, A., Laudan, R., Barker, P., Brown, H., Leplin, J., Thagard, P. \& Wykstra, S. (1986) Scientific change: Philosophical models and historical research. Synthese, 69, 141-223. 
Lederman, N. G. (1992). Students’ and teachers' conceptions of the nature of science: A review of the research. Journal of Research in Science Teaching, 29(4), 331359.

Lederman, N. G. (2006). Research on nature of science: Reflections on the past, anticipations of the future. Asia-Pacific Forum on Science Learning and Teaching. Available on-line at: http://www.ied.edu.hk/apfslt/v7_issue1/foreword/index.htm Lederman, N.G. (2007). Nature of science: Past, present, and future. In S.K. Abell \& N.G. Lederman (Eds.), Handbook of Research on Science Education (pp.831879). Mahwah, NJ: Lawrence Erlbaum Associates.

Lederman, N. G., Abd-El-Khalick, F., Bell , R.L. \& Schwartz, R. S. (2002). Views of nature of science questionnaire: Toward valid and meaningful assessment of learners' conceptions of nature of science. Journal of Research in Science Teaching, 39(6), 497-521.

Lederman, N.G., Schwartz, R.S., Abd-El-Khalick, F. \& Bell, R.L. (2001) Pre-service teachers' understanding and teaching of nature of science: An intervention study. Canadian Journal of Science, Mathematics and Technology Education, 25(8), 923-948.

Lin, H.S. \& Chen, C.C. (2002) Promoting preservice chemistry teachers’ understanding about the nature of science through history. Journal of Research in Science Teaching, 39, 773-792.

Longbottom, J.E. \& Butler, P.H. (1999). Why teach science? Setting rational goals for science education. Science Education, 83(4), 473-492.

Longino, H.E. (1990). Science as Social Knowledge: Values and Objectivity in Scientific Inquiry. Princeton, NJ: Princeton University Press. 
Loo, S.P. (1996). The four horsemen of Islamic science: A critical analysis. International Journal of Science Education, 18(3), 285-294.

McComas, W. F. (1998). The principal elements of the nature of science: dispelling the myths. In W. F. McComas (Ed), The Nature of Science in Science Education: Rationales and Strategies (pp. 41-52). Dordrecht: Kluwer.

McComas, W. F. \& Olson J. K. (1998). The nature of science in international science education standards documents. In W.F. McComas (Ed), The Nature of Science in Science Education: Rationales and Strategies (pp. 41-52). Dordrecht: Kluwer.

McCook, A. (2006). Is peer review broken? The Scientist, 20(2), 26-31. (Available at www.the-scientist.com)

Merton, R.K. (1973) The Sociology of Science: Theoretical and Empirical Investigations. Chicago, IL: University of Chicago Press.

Millar, R. \& Osborne, J. (eds) (1998). Beyond 2000: Science Education for the Future. (London: King's College)

Milne, C. (1998). Philosophically correct stories? Examining the implications of heroic science stories for school science. Journal of Research in College Teaching, 35(2), 175-187.

Mitroff, I.I. (1974) The Subjective Side of Science: A Philosophical Inquiry into the Psychology of the Apollo Moon Scientists. Amsterdam: Elsevier.

Monhardt, R. M., Tillotson, J. W. \& Veronesi, P. D. (1999). Same destination, different journeys: A comparison of male and female views on becoming and being a scientist. International Journal of Science Education, 21(5), 533-551.

Moss, D. M., Abrams, E. D. \& Robb, J. (2001). Examining student conceptions of the nature of science. International Journal of Science Education, 23(8), 771-790. 
National Research Council (NRC) (1996). National Science Education Standards. Washington, DC: National Academy Press.

Organization for Economic Cooperation and Development (OECD) (1999). Measuring Student Knowledge and Skills. Paris: OECD.

Osborne, J., Collins, S., Ratcliffe, M., Millar, R., \& Duschl, R. (2003). What “ideasabout-science” should be taught in school science? A Delphi study of the expert community. Journal of Research in Science Teaching, 40(7), 692-720.

Roth, W-M. (1995) Authentic School Science: Knowing and Learning in OpenInquiry Science Laboratories. Dordrecht: Kluwer.

Rudolph, J. L. (2000). Reconsidering the 'nature of science' as a curriculum component. Journal of Curriculum Studies, 32(3), 403-419.

Rudolph, J. L. (2003). Some thoughts on portraying epistemology in today's classrooms: A reply to Garrison. Science Education, 87(1), 90-93.

Ryder, J., Leach, J. \& Driver, R. (1999). Undergraduate science students’ images of science. Journal of Research in Science Teaching, 36(2), 201-219.

Samarapungavan, A., Westby, E. L. \& Bodner, G. M. (2006). Contextual epistemic development in science: A comparison of chemistry students and research chemists. Science Education, 90, 468 - 495.

Sardar, Z. (1989). Explorations in Islamic science. London:Mansell.

Schwartz, R. \& Lederman, N. G. (2006). Exploring contextually-based views of NOS and scientific inquiry: What scientists say. Paper presented at the National Association for Research in Science Teaching (NARST) Annual Conference, San Francisco, CA, April. 
Schwartz, R. \& Lederman, N. (2008). What scientists say: Scientists’ views of nature of science and relation to science context. International Journal of Science Education, 30(6), 727-771.

Schwartz, R.S., Lederman, N.G., \& Crawford, B.A. (2004). Developing views of nature of science in an authentic context: An explicit approach to bridging the gap between nature of science and scientific inquiry. Science Education, 88, 610-645.

Service, R.F. (2002). Bell labs fires star physicist found guilty of forging data. Science, 298, 30-31.

Service, R.F. (2003) More of Bell labs physicist papers retracted. Science, 299, 31.

Smith, M.U., Lederman, N.G., Bell, R.L., McComas, W.F. \& Clough, M.P. (1997) How great is the disagreement about the nature of science: A response to Alters. Journal of Research in Science Teaching, 34(10), 1101-1103.

Stanley, W.B. \& Brickhouse, N.W. (2001). Teaching sciences: The multicultural question revisited. Science Education, 85(1), 35-49.

UNESCO (1993). International Forum on Scientific and Technological Literacy for All. Final report. Paris: UNESCO.

Weinberg, S. (1994). Response to Steve Fuller. Social Studies of Science, 24, 748-750.

Weinstein, M. (2008) Finding science in the school body: Reflections on transgressing the boundaries of science education and the social studies of science. Science Education, 92(3), 389-403.

Wolpert, L. (1995). Response to Steve Fuller. Social Studies of Science, 24, 745-747. Young, R.M. (1987). Racist society, racist science. In D. Gill \& L. Levidow (Eds), Anti-Racist Science Teaching (pp. 16-42). London: Free Association Books. 
Wong, S. L., \& Hodson, D. (2009a). From the horse's mouth: What scientists say about scientific investigation and scientific knowledge. Science Education, 93(1), 109130.

Wong, S. L., Hodson, D., Kwan, J., \& Yung, B. H. W. (2009b). Turning crisis into opportunity: Nature of science and scientific inquiry as illustrated in the scientific research on severe acute respiratory syndrome. Science \& Education, 18(1), 95118. Another researcher and Author. (1999).

\section{Notes}

1. Davson-Galle (2008) provides a robust counter view, arguing that NOS should not be part of a compulsory science curriculum.

2. Of course, historians of the philosophy of science (e.g. Losee (1993) and Heidelberger and Stadler (2002)) tell us that NOS knowledge has changed as science itself has changed, and so we can't simply look to the past for guidance on the present concerns of NOS knowledge.

3. Lederman et al. (2002) state: "laws are descriptive statements of relationships among observable phenomena... Theories, by contrast, are inferred explanations for observable phenomena or regularities in those phenomena” (p.500). Interestingly, this is not a distinction that scientists regard as important (Wong \& Hodson, 2009a).

4. In recent publications, Lederman $(2006,2007)$ seeks to restrict use of the term nature of science to the characteristics of scientific knowledge (i.e., to epistemological considerations). In common with definitions adopted by Osborne et al. (2003) and Clough (2006), our conception of NOS encompasses the characteristics of scientific inquiry, the role and status of the scientific 
knowledge, how scientists work as a social group, and how science impacts, and is impacted by, the social context in which it is located.

5. Merton first outlined this theoretical framework in a 1942 essay titled "Science and technology in a democratic order", published in the Journal of Legal and Political Sociology.

6. After the submission of our previous paper (Wong \& Hodson, 2009a), an opportunity arose for another world-renowned scientist to participate in the research. He had been invited by a local university to give a public lecture "Encounters with Modern Physics” in which he shared with the audience some reflections on his vast research experience. His acceptance of our invitation increased the total number of participating scientists reported in this paper to fourteen.

7. It is important to recognize that the impact of reputation on reviewers' appraisals is not necessarily detrimental to good science. Long-standing, prestigious research groups have established their reputations for quality work by developing trustworthy ways of doing things. 
TABLE 1: Details of the Participating Scientists

\begin{tabular}{|c|c|c|}
\hline Scientists & Current Major Areas of Research & $\begin{array}{l}\text { Research } \\
\text { experience } \\
\text { (Years/Places } \\
\text { of work) }\end{array}$ \\
\hline $\begin{array}{l}\text { Theoretical High Energy } \\
\text { Physicist }\end{array}$ & $\begin{array}{l}\text { High energy physics, cellular automata and } \\
\text { morphology dependent resonances }\end{array}$ & $\begin{array}{l}17 \\
\text { UK, USA, } \\
\text { China }\end{array}$ \\
\hline $\begin{array}{l}\text { Experimental High Energy } \\
\text { Physicist }\end{array}$ & $\begin{array}{l}\text { Coordinating an international project in } \\
\text { building a space-borne cosmic ray detector }\end{array}$ & $\begin{array}{c}47 \\
\text { USA, } \\
\text { Switzerland }\end{array}$ \\
\hline Experimental Particle Physicist & $\begin{array}{l}\text { Elementary particle physics, radiation } \\
\text { shielding calculation }\end{array}$ & $\begin{array}{l}14 \\
\text { UK, USA, } \\
\text { Switzerland }\end{array}$ \\
\hline Materials Scientist & $\begin{array}{l}\text { Material characterization, spectroscopy, } \\
\text { microscopy of nanostructures }\end{array}$ & $\begin{array}{c}19 \\
\text { UK }\end{array}$ \\
\hline Theoretical Astrophysicist & $\begin{array}{l}\text { Astrophysics, quantum mechanical } \\
\text { computation and nonlinear physics }\end{array}$ & $\begin{array}{c}16 \\
\text { USA, China }\end{array}$ \\
\hline $\begin{array}{l}\text { Theoretical Solid State } \\
\text { Physicist }\end{array}$ & $\begin{array}{l}\text { Electronic and optical properties of rare } \\
\text { earth ions in crystals, application of group } \\
\text { theory to spectroscopy }\end{array}$ & $\begin{array}{l}26 \\
\text { New Zealand, } \\
\text { USA, China }\end{array}$ \\
\hline Cancer Biologist & Cancer research and its applications & $\begin{array}{c}32 \\
\text { China }\end{array}$ \\
\hline Medical Geneticist & $\begin{array}{l}\text { DNA test on prenatal diagnosis, cancer } \\
\text { detection and monitoring }\end{array}$ & $\begin{array}{c}20 \\
\text { UK, China }\end{array}$ \\
\hline Virologist & $\begin{array}{l}\text { Molecular determinants of influenza genes, } \\
\text { vaccine research }\end{array}$ & $\begin{array}{l}10 \\
\text { UK, China }\end{array}$ \\
\hline Molecular Biologist & $\begin{array}{l}\text { Molecular Biology, genomics, } \\
\text { bioinformatics }\end{array}$ & $\begin{array}{c}13 \\
\text { China }\end{array}$ \\
\hline Stem Cell Biologist & Stem cells and gene transfer & $\begin{array}{c}26 \\
\text { Australia, China }\end{array}$ \\
\hline Cell Biologist & Cell cycle control, regulation of cell size & $\begin{array}{l}20 \\
\text { UK, China }\end{array}$ \\
\hline Biochemist & $\begin{array}{l}\text { Construction and characterization of hybrid } \\
\text { enzymes, protein engineering }\end{array}$ & $\begin{array}{l}15 \\
\text { UK, China }\end{array}$ \\
\hline $\begin{array}{l}\text { Director of Research Initiatives } \\
\text { (formerly experimental } \\
\text { semiconductor physicist) }\end{array}$ & $\begin{array}{l}\text { Creating research partnerships between } \\
\text { government, industry, and the university }\end{array}$ & $\begin{array}{c}15 \\
\text { UK,USA }\end{array}$ \\
\hline
\end{tabular}

